\title{
Konsep Pengampunan Menurut Matius 18:21-35 dan Implikasinya bagi Gereja Masa Kini
}

\author{
Herry Jeuke Nofrie Korengkeng \\ Sekolah Tinggi Teologi Kalimantan \\ Korespondensi: herryjnkorengkeng@sttkalimantan.ac.id
}

\begin{abstract}
Abstrak
Alkitab mengajarkan suatu kebenaran konkrit yang merupakan dasar kuat dalam pembahasan tentang pengampunan. Pengampunan adalah aspek penting yang tidak bisa dipisahkan dari kehidupan orang percaya. Pemahaman yang salah tentang eksistensi orang percaya pada saat diampuni dapat menimbulkan permasalahan. Karena itu pengampunan menurut Yesus dalam Matius 18:21-35 sangat penting dihubungkan dengan hidup orang percaya. Adapun tujuan dalam penelitian ini adalah supaya dasar yang diletakkan oleh Yesus sehubungan dengan pengampunan menjadi pola kehidupan orang percaya. Orang percaya dimotivasi agar dapat merealisasikan pengampunan yang diajarkan oleh Yesus. Melalui metode kualitatif dengan jenis penelitian tekstual atau penelitian literatur murni ditemukan pemahaman bahwa mengampuni tanpa batas merupakan tuntutan Allah bagi setiap orang percaya. Pengampunan yang diberikan Allah di dalam Yesus Kristus didasarkan pada belas kasihan Allah. Setiap orang yang percaya Yesus menerima pengampunan dari Allah oleh belas kasihan Allah yang besar. Yesus mengajarkan setiap orang percaya untuk mengampuni karena telah menerima belas kasihan Allah. Sikap ini perlu diambil dan diaplikasikan oleh setiap orang percaya yang telah menerima pengampunan dari Allah didalam Yesus Kristus.
\end{abstract}

Kata-kata kunci: Matius, pengampunan, raja, hamba, belas kasihan

\begin{abstract}
The Bible teaches a concrete truth that is a strong basis in the discussion of forgiveness. Forgiveness is an important aspect that cannot be separated from the life of a believer. Incorrect understanding of the existence of believers when forgiven can cause problems. Therefore forgiveness according to Jesus in Matthew 18: 21-35 is very important related to the life of the believer. The purpose of this research is that the foundation laid by Jesus regarding forgiveness becomes the pattern of the life of the believer. Believers are motivated to realize the forgiveness taught by Jesus. This is very necessary for spiritual life and service in the present and the future. Through a qualitative method with the type of textual research or pure literary research found that understanding that forgiving without limits is God's demand for every believer. Forgiveness given by God in Jesus Christ is based on God's mercy. Everyone who believes in Jesus receives forgiveness from God by God's great mercy. Jesus taught every believer to forgive for receiving God's mercy. This attitude needs to be taken and applied by every believer who has received forgiveness from God in Jesus Christ.
\end{abstract}

Keywords: Matthew, forgiveness, king, servant, mercy 


\section{PENDAHULUAN}

Alkitab mengajarkan suatu kebenaran konkrit yang merupakan dasar kuat dalam pembahasan tentang pengampunan. Pengampunan adalah aspek penting yang tidak bisa dipisahkan dari kehidupan orang percaya. Pengampunan menurut Yesus dalam Matius 18:21-35 sangat penting dihubungkan dengan hidup orang percaya. Yesus mengajarkan pengampunan tanpa batas melalui suatu perumpamaan dalam Matius 18:21-35. Pemahaman yang salah tentang eksistensi orang percaya pada saat diampuni dapat menimbulkan permasalahan seperti yang diungkapkan Goldi Bristol dan Caril McGinnis: "Saya juga heran melihat betapa kurangnya ajaran tentang tanggung jawab orang Kristen untuk mengampuni." Senada dengan yang dikatakan Bristol dan McGinnis, alasan penelitian teks ini diangkat adalah karena pengampunan mulai dikesampingkan dan tidak diutamakan lagi, akibatnya terjadi penyimpangan-penyimpangan. Pada hakikatnya hal ini dituntut oleh Alkitab sendiri, baik secara doktrinal maupun praktikal.

Pengampunan yang diberikan Allah di dalam Yesus Kristus didasarkan pada belas kasihan Allah. Hal ini terlihat jelas dalam perumpamaan ini sebagaimana hamba yang berhutang itu dituntut agar melunasi hutangnya. Oleh belas kasihan raja itu, hamba yang berhutang banyak dibebaskan. Perumpaman ini mengungkapkan suatu kebenaran hakiki tentang pengampunan Yesus. Setiap orang yang percaya Yesus menerima pengampunan dari Allah oleh belas kasihan Allah. Yesus mengajarkan setiap orang percaya untuk mengampuni karena telah menerima belas kasihan Allah. Sikap ini perlu diambil dan diaplikasikan oleh setiap orang percaya yang telah menerima pengampunan dari Allah didalam Yesus Kristus.

\section{METODE}

Metode yang digunakan dalam penelitian ini adalah metode kualitatif melalui penelitian hermeneutik dan penelusuran berbagai literatur yang mendukung pembahasan. Dengan kata lain karya ini bersifat konseptual atau teoritis dan merupakan hasil penelitian kepustakaan dalam rangka memecahkan permasalahan yang ditemukan dan dikemukakan.

Adapun prosedur penelitian yang dilakukan meliputi penelitian teks dan beberapa kata kunci dalam perikop yang diteliti. Selanjutnya penelitian terhadap perikop inti dilakukan dengan mempertimbangkan konteks penulisan, kesejarahan, dan tata bahasa. Penelusuran berbagai literatur pendukung juga menjadi bagian yang dilakukan dalam penyelidikan teks.

\section{PEMBAHASAN}

\section{Konsep Pengampunan Menurut Matius 18:21-35}

Pengampunan adalah suatu kebenaran mutlak dari kasih karunia Allah. Richard Strauss berkata,

Ketika Yesus Kristus menundukkan kepala-Nya untuk menyerahkan nyawa-Nya, Ia berseru, 'sudah selesai.' Kata itu ditulis dalam teks bahasa Yunani, sebuah kata yang kadang-kadang dipakai untuk transaksi dagang pada waktu itu, kalau ditulis di sehelai kwitansi kata itu berarti, 'Lunas.' Tak ada yang dapat kita tambahkan kepada apa yang telah dilakukan Kristus, tak ada yang kita lakukan yang membuat kita layak menerima pengampunan-Nya dan tidak ada yang dapat kita bayar untuk memperolehnya. Allah di dalam kasih karunia-nya telah membayar penuh pelanggaran-pelanggaran kita dan telah membebaskan kita dari kesalahan kita untuk selama-lamanya. Kasih karunia itu berada pada inti pengampunan. ${ }^{2}$

Mazmur 130:4 berkata, "Pada-Mu ada pengampunan, supaya engkau ditakuti orang." Perjanjian Lama tidak mengenal Allah yang tidak mau mengampuni atau harus disuap supaya rela mengampuni. Pengampunan terjadi hanya karena Allah sudi mengampuni (Neh 9:17). "Pada Tuhan Allah kami ada kesayangan dan

\footnotetext{
${ }^{2}$ Richard Strauss, Hubungan yang Harmonis
} (Bandung: Kalam Hidup, 1985), 11. 
keampunan (Dan 9:9).” ${ }^{3}$ Dalam Alkitab Perjanjian Baru, istilah pengampunan berasal dari istilah Yunani $\alpha \phi \imath \varepsilon \mu \iota$ (aphiemi). Istilah ini adalah kini aktif indikatif. ${ }^{4}$ Dalam pemakaian ini jelas dinyatakan bahwa istilah $\alpha \phi \imath \varepsilon \mu$ m menunjuk kepada suatu tindakan yang terus menerus dilakukan. H. Vorlander menjelaskan istilah $\alpha \phi \imath \varepsilon \mu \iota$ sebagai berikut: aphiemi (devided from apo, from, and hiemi, to put in motion, send), attested since homer, means the voluntary releas of aperson or thing over which on has legal or actual control. ${ }^{5}$

Dalam Perjanjian Baru terdapat dua kata kerja yaitu kharizomai (melakukan secara anugerah), aphiemi dan kata benda aphesis (melepaskan). ${ }^{6}$ Istilah kharizomai mempunyai arti memberi, mengaruniakan, memperlakukan dengan murah hati, mengampuni, menyerahkan atau melepaskan, menghapus piutang.? Demikian juga Donald Guthrie menjelaskan bahwa kata kharizomai menambah suatu dimensi lain lagi pada gagasan pengampunan yaitu gagasan tentang anugerah yang diterapkan baik kepada perbuatan Allah atas kita berkenaan dengan dosa, maupun kepada perbuatan kita satu sama lain. ${ }^{8}$ Hal inilah yang dimaksud Paulus dalam Efesus 4:32.

Ben Ferguson dalam bukunya menuliskan:

Kita harus menunjukkan kebaikan kepada mereka yang tidak menyukai kita, terlepas dari apapun yang terjadi. Sedangkan mengampuni harus kita praktekkan kepada orang-orang yang telah melukai hati kita. ${ }^{9}$

3 "Leon Morris, "Pengampunan" dalam Ensiklopedi Alkitab Masa Kini Jilid I, (Jakarta: Yayasan Komunikasi Bina Kasih/OMF, 1997), 45.

${ }^{4}$ Walter Baur, Greek English Lexicon of the Old

Testamen and Other Early Christian Literature (Chicago: University of Pres, 1979), 125.

${ }^{5} \mathrm{H}$. Vorlander, The New International Dictionary of The New Testament Teology, (Grand Rapids: Zondervan Publishing House, 1969), 697.

${ }^{6}$ Leon Morris 'Aphiemi' dalam Ensiklopedi Alkitab Masa Kini Jilid I, 45.

${ }^{7}$ Barclay M. Newman Jr., "kharizomai" dalam

Kamus Yunani Indonesia, 125.

${ }^{8}$ Donald Guthrie, Teologi Perjanjian Baru (bandung: BPK Gunung Mulia, 1993), 2:238.

${ }^{9}$ Ben Ferguson, Cara Mengatasi 12 Maslah Kehidupan (Solo: Dabara Publisher, 1995), 22.
Pernyataan di atas diperjelas dengan menggunakan pengertian istilah kharizomai sebagai berikut:

Kata "mengampuni" (kharizomai) adalah sebuah kata sifat yang menunjukkan tindakan yang terus menerus dilakukan. Kata ini berarti mengampuni dengan tanpa ikatan, tidak mendendam atau mengomel. Cobalah anda merenungkan! Kita harus belajar mengampuni atas segala yang telah dilakukan orang lain terhadap kita, meskipun mereka tidak memintanya. Kita harus meminta pengampunan dari orang-orang yang telah kita sakiti dan mengampuni orang-orang yang telah menyakiti hati kita. Sebuah tindakan revolusioner! Kita bertanggungjawab untuk berbuat baik dan mengampuni orang lain. Dengan mempraktekkan hal itu, kita akan dapat mengatakan "selamat tinggal" kepada akar kepahitan. ${ }^{10}$

Jadi jelas bahwa pengampunan yang diberikan Allah bertujuan untuk menunjukkan kepada orang percaya betapa panjangnya pengampunan sempurna tersebut. Standar Allah berbunyi: sama seperti Kristus telah mengampuni kamu.

Matius secara mendetail mencatat inti pengajaran Yesus ini yang berbunyi: "Tuhan, sampai berapa kali aku harus mengampuni saudaraku jika ia berbuat dosa terhadap aku? Sampai tujuh kali?' Yesus berkata kepadanya: 'Bukan! Aku berkata kepadamu: Bukan sampai tujuh kali, melainkan sampai tujuh puluh kali tujuh kali”" (Mat. 18:21-22).

Yesus dengan tidak mengabaikan tanggungjawab-Nya sebagai guru sangat berkepentingan menjelaskan kepada Petrus tentang masalah mengampuni. Kepentingan dari tanggung jawab-Nya sebagai guru adalah mau meluruskan pikiran Petrus dan para pengikut Yesus beserta orang percaya pada umumnya tentang pengampunan yang sesungguhnya. Sebab pengampunan Kristus tidak dapat dijangkau atau diukur oleh akal sehat maupun intelektual (pikiran) manusia. Itulah prinsip yang terkandung dalam karya salib Kristus.

Dalam ayat 21 dengan jelas diberitahukan bahwa Petrus secara spontan melontarkan pertanyaan kepada Yesus. Ungkapan "berbuat dosa” yang disebutkan oleh Yesus dalam ayat 21
${ }^{10}$ Ibid. 
adalah menjelaskan bahwa karena dosalah yang menyebabkan sehingga orang-orang itu menyimpang dari jalur kejujuran dan berbuat salah. Hal inilah yang menyebabkan hubungan Allah dan manusia terputus. Alkitab melaporkan dengan jelas bahwa kematian rohani itu dimulai dari jatuhnya Adam dan Hawa ke dalam dosa di taman Eden (Kejadian 3). Charles C. Ryrie berkata bahwa, "keterpisahan Allah dengan manusia itu berpengaruh besar secara universal (Roma. 3:23)." ${ }^{\prime 11}$ Dosa adalah istilah yang umum dipakai untuk melukiskan gagasan kegagalan manusia, sikap menentang bahkan keterpisahan manusia dari Allah secara bebas. Untuk memperoleh kembali status dan kedudukan dihadapan Allah, maka dosa perlu penyelesaian. Jalan satu-satunya yang telah ditetapkan Allah adalah salib Kristus. Inilah satu-satunya karya yang dapat mempersatukan kembali manusia dengan Allah.

James Montgomery Boice menjelaskan dalam Tractate Joma bahwa Rabbi Jose Bin menulis sebagai berikut: "Jika seseorang saudaramu berdosa terhadap engkau satu kali, ampunilah dia, kedua kalinya ampunilah dia dan ketiga kalinya ampunilah dia." ${ }^{12}$ Hal inilah yang mungkin menjadi acuan dasar Petrus, sehingga dia bertanya kepada Yesus. Pertanyaan Petrus bukan saja baik tetapi juga relevan, sampai sejauh mana batas diberikan sehubungan dengan pengampunan. Petrus merasa sangat murah hati pada waktu itu, karena peraturan yang berlaku menurut guru-guru Yahudi adalah tiga kali. Dapat dikatakan di sini bahwa pertanyaan tersebut adalah sesuatu yang telah lama diperdebatkan oleh para guru Taurat dan Petrus mungkin mendasarkan pertanyaan pada apa yang didengarnya pada waktu itu. Frank E. Gaebelein berkata bahwa:

"Then" (v.21) is probably to be taken strictly (see on 3:13). The issue is not the adjudication of the church, still less the absolute granting of forgiveness by the church (only God and Jesus can forgive sins in so absolute a fashion), but personal forgiveness (cf.6:14-15). In rabbinic discussion the consensus was that a brother might be forgiven a repeated sin three times; on the fourth, there

\footnotetext{
${ }^{11}$ Charles C. Ryrie, Teologi Dasar 1, 7.

12 James Montgomery Boice, PerumpamaanPerumpamaan Tuhan Yesus (Surabaya: Yakin, 1983), 200.
}

is no volunteers "seven times" in answer to his own question-a laeger figure often used, among other things, as a "round number" (cf. lev 26:21; Deut 28:25; Ps 79:12; Prov 24:16; Luk 17:4). ${ }^{13}$

Pengampunan Yesus berbeda dengan ajaran para rabi dan guru-guru Taurat yang hanya dibatasi sampai tiga kali. Jadi, tidak heran Petrus tentu mendengar diskusi semacam itu. Itulah sebabnya ketika Petrus bertanya kepada Yesus apakah ia harus mengampuni seseorang sampai tujuh kali karena ia merasa telah mencapai puncak kemurahan hati. Lagi pula guru-guru Taurat mengajar bahwa orang hanya boleh diberi ampun sampai tiga kali saja. G. Campbell Morgan menjelaskan bahwa, "The teaching of all the scribes and Rabbis was, forgive once, forgive twice, but the third offence merits no forgiveness." ${ }^{14}$ Charles R. Swindol menjelaskan bahwa Petrus menggandakan batas yang dia anggap baik, kemudian Tuhan menanggapi. Bukan sampai tujuh kali melainkan sampai tujuh puluh tujuh kali (Mat. 18:22). ${ }^{15}$

Dalam buku Tafsiran Alkitab Masa Kini 3 dijelaskan tentang bilangan tujuh puluh kali tujuh kali sebagai berikut:

Tujuh puluh kali tujuh kali: ada juga naskah yang menyatakan 'tujuh puluh kali tujuh kali' ini adalah kebalikan sepenuhnya dari keadaan sebelum hukum taurat menetapkan peraturan pembalasan yang setimpal (Kel.21:24; bnd. Mat.5:38) 'sebab jika kain harus dibalas tujuh kali lipat, maka Lamekh tujuh puluh tujuh kali lipat' (Kej. 4:24). Begitu juga halnya dengan pengampunan, pengampunan harus juga tidak ada batasnya. ${ }^{16}$

Hukum Taurat menetapkan peraturan pembalasan yang setimpal. Dengan kata lain, maksud dari hal ini adalah setiap orang yang

\footnotetext{
${ }^{13}$ Frank E. Gaebelein, The Expositor's Bible
} Comentary Volume 8 (Grand Rapids, Michigan: Regency Reference Library Zondervan Publishing House, 1984). 405.

${ }^{14}$ G. Campbell Morgan, The Gospel According to Mattew (Old Tappan, New Jersey: Fleming H. Revell Company, 1978), 235.

${ }^{15}$ Charles R. Swindol, Tingkatkan Pelayanan Anda (Jakarta: BPK Gunung Mulia, 1985) 102.

${ }^{16}$ Tafsiran Alkitab Masa Kini 3 (Jakarta: Yayasan

Komunikasi Bina Kasih/OMF, 1976), 102 
melakukan suatu kesalahan terhadap sesamanya atau berbuat jahat harus dibalas sesuai dengan perbuatannya. Perlakuan ini sesuai dengan peraturan yang berlaku pada zaman Hukum Taurat, di mana tidak ada hukum yang menentang untuk hal itu. Frank E. Gaebelein menjelaskan bahwa:

Jesus response (v.22) alludes to Genesis 4:24 (cf. Notes): Lamech's revenge is transformed into a principle of forgiveness. In this context Jesus is not saying that seventy-seven times is the upper limit, nor that the forgiveness is so ungquallified it vitiates the discipline and procedural steps just of fellows members in his community of "little ones" brothers) can not possible be limited by frequency or quantity; for, as the ensuing parable shows (vv.23-35), all of them have been forgiven far more than they will ever forgive. ${ }^{17}$

Tanggapan Yesus dalam ayat 22 menyinggung Kejadian 4:24 dimana pembalasan Lamekh diubah menjadi prinsip pengampunan. Dalam konteks ini Yesus tidak mengatakan bahwa tujuh puluh tujuh kali adalah batas atas karena, seperti yang ditunjukkan perumpamaan berikutnya (ayat 23-35), semuanya telah diampuni jauh lebih banyak daripada yang akan mereka ampuni. Yesus tidak berkata bahwa tujuh puluh kali tujuh kali adalah batas terakhir atau batas teratas, maupun bahwa pengampunan itu memenuhi syarat serta meniadakan disiplin dan langkah-langkah prosedur yang telah diajarkan (Mat. 18:15-20). Dengan perkataan itu Tuhan Yesus berkata bahwa pengampunan itu tidak terbatas berapa kali, melainkan tanpa batas. Petrus meyangka ada batas untuk hal mengampuni sesamanya. Sangkanya bahwa mengampuni tujuh kali sudah hebat dan sudah cukup. Sehubungan dengan hal ini, Jhon. F. Walvoord dan Roy B. Zuck menjelaskan sebagai berikut:

Peter was being generous here for the traditional Rabinic teaching was that an offended person needed to forgive a brother only three times. Jesus reply was that forgiveness needs to be exercised to a much graeter extent. Not just 7

${ }^{17}$ Frank E. Gaebelein, The Expositor's Bible Comentary Volume 8, 408. times, but "70 times 7" (Niv marg.), that is 490 times . Jesus meant that no limits sould be set. ${ }^{18}$

Petrus bersikap murah hati ketika membandingkan dengan pengajaran rabinis yang hanya mengampuni seorang saudara hanya tiga kali. Yesus menjawab bahwa pengampunan itu tidak hanya 7 kali, tetapi "70 kali 7," yaitu 490 kali. Yesus memaksudkan bahwa tidak ada batasan yang dapat ditentukan. Dengan kata lain Pengampunan Yesus itu adalah tanpa batas

J. J. De Heer menguatkan argumen di atas dengan menjelaskan bahwa:

Sudah tentu Yesus juga ingat akan Lamekh yang mau membalas dendam, sebab jika Kain harus dibalas tujuh kali lipat, maka Lamekh tujuh puluh kali lipat (Kejadian 4:24), menurut dia alam pikiran Yesus bertentangan dengan alam pikiran Lamekh. ${ }^{19}$

Pernyataan J. J. De Heer di atas dipertegas oleh James Montgomery Boice dengan mengomentari hal tersebut sebagai berikut: "pikiran manusia bukan pikiran Allah." ${ }^{20}$ Lebih lanjut lagi, J. H. Bavink menjelaskan bahwa "berhitung seperti konsep pemikiran Petrus adalah sangat bodoh dan sangat bertentangan dengan ke-Kristenan." ${ }^{21}$

Yesus berkata bahwa jawaban itu sebenarnya telah tertera dalam Injil Matius 18:22. Tetapi Petrus dalam hal ini salah membaca situasi. Jawaban Yesus ialah tidak Petrus, Bukan tujuh kali melainkan tujuh puluh kali tujuh kali yakni 490 kali. Maksud Yesus adalah bahwa orang percaya harus mengampuni orang lain tanpa batas. Sehubungan dengan hal ini, A. A Sitompul menambahkan bahwa:

Matius 16:19 (ps 122): kepadamu akan Ku berikan kunci kerajaan sorga. Apa yang kau ikat di dunia ini akan terikat di sorga dan apa yang kau lepaskan di dunia ini akan terlepas di sorga. Atau, tujuh

${ }^{18}$ Jhon F. Walvoord dan Roy B. Zuck, The Bible

Knowledge Commentary (Engliand: Victory Book

Publication, 1984), 62

${ }^{19}$ J.J. De Heer, Tafsiran Alkitab Injil Matius 2

(Jakarta: BPK Gunung Mulia, 1985), 102.

20 James Montgomery Boice, Perumpamaan-

Perumpamaan Tuhan Yesus, 2000.

${ }^{21}$ J.H. Bavink, Sejarah Kerajaan Allah (Jakarta: BPK

Gunung Mulia, 1982), 352. 
puluh tujuh kali, Bnd. Kej.4:24 artinya dalam nats Yunani selalu tanpa batas. ${ }^{22}$

Jika Petrus menyadari tentang apa yang telah dibuat Yesus pasti dia tidak akan membuat suatu perhitungan dalam hal mengampuni. Matius 18:18 menjelaskan bahwa sesungguhnya Allah telah menyatakan pengampunan-Nya kepada orang percaya. Karena menurut, P. Marc Van Den Berghe "Allah mengampuni tanpa syarat, tanpa tuntutan, tidak ada rasa yang terpendam." 23 Inilah dasar yang diletakkan oleh Yesus supaya dapat teraplikasikan dalam kehidupan orang percaya. Sebab itu Warren W. Wiersbe berkata, "pengampunan diberikan secara cuma-cuma, tidak murah tapi mahal sebab Yesus menyerahkan hidup-Nya di salib untuk menanggung dosa manusia." 24 Geoffey W. Bromley berkata:

\begin{abstract}
Sebab itu tidaklah mengherankan kita mendapatkan Yesus menyatakan mempunyai kekuasaan untuk mengampuni dosa-dosa. Hal ini menimbulkan tantangan bagi orang-orang Yahudi, sebab bagi mereka merupakan aksioma kecuali hanya Tuhan Allah (Mark. 2:7; Luk. 5:21; 7:49). Hal ini Yesus tidak mempertanyakan tetapi Ia ingin mereka mengakui kuasa-Nya untuk mengampuni dosa bahwa ialah pemilik kuasa Ilahi. ${ }^{25}$
\end{abstract}

Yesus memberikan kuasa atau kemampuan untuk mengampuni sebab orang percaya sudah memiliki Kristus. Pengampunan Kristus adalah dasar untuk membangun suatu gaya hidup yang rela mengampuni orang lain. Goldie Bristol, mengutip pertanyaan Wayne Grudem menjelaskan bahwa "suatu penjelasan umum yang dipegang oleh para penafsir Alkitab ialah hati yang pengampun merupakan bukti bahwa orang itu sudah diselamatkan." ${ }^{26}$ Kasih adalah

${ }^{22}$ A.A Sitompul, Sinopsis Ketiga Injil

(Jakarta:Lembaga Alkitab Indonesia, 1993), 116.

${ }^{23}$ P. Marc Van Den Berghe, Akula Jalan (Jakarta:

BPK Gunung Mulia, 1994), 212.

${ }^{24}$ Warren W. Wiersbe, Meet Yourself in the Parables

(Victor Book: Publication Inc., 1979), 49.

${ }^{25}$ Geoffey W. Bromiley, The International Standar

Bible Encyclopedia (Grand Rapids : William B. Eedmans Publishing Company, 1979), 342.

${ }^{26}$ Goldie Bristol dan McGinnis Carol, Haruskah Saya Mengampuni , 29. bukti bahwa orang percaya adalah murid-murid Kristus (Yoh. 13:34-35). Kasih lebih sekedar emosi, kasih adalah perbuatan yang aktif, nyata dan kasih merupakan ketaatan yang dilakukan sekarang juga. Mengampuni berarti orang percaya harus mengampuni, karena mengampuni berarti berkorban karena mengasihi orang lain. mengampuni menyangkut banyak hal tetapi di atas segala-galanya mengampuni itu diperintahkan oleh Allah, dan mengampuni bukan soal mau atau tidak melainkan suatu keharusan.

Dengan saling mengampuni orang percaya akan memelihara kesatuan di dalam tubuh Kristus dan merupakan kesaksian yang sangat mengesankan bagi Kristus sendiri. sebab harga yang harus dibayar oleh Kristus untuk mengampuni orang percaya dimulai ketika Ia mengambil keputusan untuk datang ke dalam dunia ini. Warren W. Wiersbe berkata: Orang percaya harus menyadari tentang hal mengampuni, sebab kalau bukan Kristus tidak mungkin ada pengampunan dosa. Itulah sebabnya dia berkata pengampunan adalah mujizat terbesar dari Allah. ${ }^{27}$

\section{Konskuensi bagi Orang yang Mengampuni}

Dalam ayat 23-27 Yesus memberikan gambaran yang jelas tentang hal mengampuni dengan menggunakan suatu perumpamaan. Hamba yang mendapat pengampunan dari seorang raja semestinya hamba tersebut juga harus mengampuni sesamanya. Hal ini terlihat jelas ketika hamba itu memohon kepada tuannya dengan berkata sabarlah dahulu, segala hutangku akan kulunaskan. Oleh belas kasihan raja itu, hamba yang berhutang banyak dibebaskan. Dalam teks Yunani, kata (Makrotumeo) yang tertera, memiliki pengertian "sabar, bersabar." 8 Kata Makrotumeo menurut Frits Rienecker dalam A Linguistic key to the Greek New Testament adalah "memiliki kesabaran." ${ }^{29}$ Kata ini adalah bentuk

49.

${ }^{27}$ Warren W. Wiersbe, Meet Yourself in the Parables,

${ }^{28}$ Harol K. Moulton, The Analytical Greek Lexicon

Revised (Gran Rapids: Zondervan, 1978). 156.

${ }^{29}$ Frits Rienecker, A Linguistic key to the Greek New

Testament, 55 . 
kini indikatif aktif yang menurut Frits Rienecker mengambil cukup banyak waktu sebelum menggerutu atau mengomel dengan berkobar-kobar. Bentuk kini indikatif aktif ini menerangkan suatu gagasan dengan memiliki gaya atau cara kebiasaan yang terus menerus menjadi berguna baik hati dan sangat ramah sekali. $^{30}$ Sehubungan dengan pernyataan di atas, Billy Graham menegaskan bahwa:

Kesabaran bukanlah sekedar daya tahan yang pasrah terhadap keadaan tertentu. Kesabaran merupakan suatu sikap yang mengandung suatu pengharapan. Seorang petani sanggup dengan sabar menatapi tanahnya yang tampak tandus karena ia percaya bahwa akan ada hasil dari pekerjaannya. Ia dapat bersabar dalam pekerjaannya karena jerih payahnya akan membawa hasil. $^{31}$

Dalam kitab Amsal sifat kesabaran sangat dipuji untuk menghindari perselisihan, juga dalam penerbitan perkara-perkara dengan bijaksana terutama jika terlibat dalam hal-hal yang menimbulkan amarah. Orang Kristen wajib menunjukkan kesabaran seperti kesabaran Allah dalam hubungan satu sama lain (Mat.18:26-29; 1 Kor.13:14; Ef.4:2; 1 Tes. 5:14. Sebab panjang sabar adalah satu dari buah Roh Kudus (Galatia 5:22). ${ }^{32}$ Kalau Allah memiliki sifat kesabaran yang luar biasa ini, bagaimana dengan orang percaya yang telah mengakui Dia sebagai Tuhan dan Juruselamat. Orang percaya wajib dan harus menunjukkan kesabaran seperti kesabaran Yesus.

Dalam Kamus Yunani Indonesia, dijelaskan bahwa kata eleeo berasal dari akar kata eleos berbentuk netral yang memberi pengertian belas kasihan rahmat (Tuhan), sedangkan bentuk genetifnya adalah kata eleemon dengan arti yang menaruh belas kasihan atau murah hati. ${ }^{33}$

Allah di dalam kasih-Nya menyatakan belas kasihan dan rahmat-Nya kepada orang yang

${ }^{30}$ Ibid, 55.

${ }^{31}$ Billy Graham, Hingga Harmagedon (Bandung: Lembaga Literatur Baptis, 1981), 302.

32 J.W.L. Hoad dkk, 'Kesabaran' dalam Ensiklopedia Alkitab Masa Kini Jilid 2M-Z (Jakarta: Yayasan Komunikasi Bina Kasih/OMF, 1996), 335.

${ }^{33}$ Barclay M. NewMan Jr., 53. memohonkannya, sehingga mendapatkan belas kasihan dari Allah. Setiap orang percaya telah mengalami belas kasihan Allah dalam hidupnya, wajib menunjukkan belas kasihan itu kepada orang yang membutuhkannya. Tindakan nyata ini, ada dalam kehidupan para Nabi dan abdi Allah karena menyadari tentang apa yang sudah dikerjakan oleh Yesus. Dalam J. W. Meiklejhon menyatakan bahwa para nabi dan abdi Allah sadar akan keajaiban rahmat dan belas kasihan Allah terhadap orang berdosa dan orang sengsara. Allah Bapa penuh dengan belas kasih (pengasih dan penyayang) (2 Kor.1:3; Kel.34:6; Neh.9:17; Maz.86:15;103:8-14;Yoel 2:13; Yunus 4:2, dan kasih-Nya (eleos) yang benar (Ef.2:4 penyelamat kita (Titus 3:5). ${ }^{34}$ Hati Yesus kerap kali tergugah oleh belas kasihan dan Ia menyuruh murid-murid-Nya menujukan belas kasihan kepada orang lain yang membutuhkan pertolongan. Belas kasihan orang percaya harus serupa dengan belas kasih-Nya, bukana hanya dalam hal bertindak dengan pengorbanan diri (1Yoh 3:17). Orang yang murah hati akan beroleh kemurahan (Mat.5:7; Bnd. Mat 21:21; Luk.6:36).

Dalam Matius 18:23-27 menjelaskan tentang raja menaruh belas kasihan kepada hambanya, hutangnya dibebaskan. Sehubungan dengan hal ini, maka R.A Jaffray secara intensif menjelaskan di bawah ini sebagai berikut:

1. Hamba itu berhutang banyak kepada tuannya. Di sini dilukiskan keadaan orang berdosa yang telah melanggar segala perintah Allah, seperti seorang hamba yang hidup berdosa sehingga hutangnya bertimbun-timbun dan akhirnya ia tidak dapat membayar kepada tuannya. Kewajiban seorang hamba kepada tuannya ialah memelihara dan menuruti perintahnya. Sebab itu hamba yang berbuat sebaliknya yaitu melanggar, tidak taat, lalai dalam melakukan perintah tentunya akan dituntut oleh tuannya. 2. Raja senantiasa ingat akan hambahambanya yang berhutang padanya. Hal ini melukiskan hambanya yang berhutang padanya. Hal ini melukiskan peristiwa yang akan terjadi kelak pada akhir zaman, di mana seluruh umat manusia akan berdiri di hadapan kursi pengadilan Kristus, hakim yang adil dan benar itu. Tuhan tidak akan

${ }^{34}$ J.W Meiklejhon 'Kasih Sayang atau Belas Kasihan' dalam Ensiklopedia Alkitab Masa Kini Jilid 2M-Z (Jakarta: Yayasan Komunikasi Bina Kasih/OMF, 1996), 528. 
melupakan segala perbuatan manusia semasa hidup di dunia ini. 3. Raja itu menaruh belas kasihan kepada hambanya lalu membebaskan hutangnya itu. Hal ini melukiskan cinta kaih Tuhan yang demikian besar kepada manusia berdosa, sehingga bukan saja hutangnya dibebaskan tetapi juga diberi kemerdekaan yang sempurna dari anugerah dan rahmat-Nya yang berkelimpahan itu. ${ }^{35}$

Berdasarkan pemahaman di atas, jelas bahwa setiap manusia yang melanggar segala perintah Tuhan pasti berhadapan dengan Allah sendiri, sebagaimana hamba yang banyak hutang itu dituntut agar malunasi hutangnya. Walaupun dosa manusia bertimbun-timbun dan membumbung seperti tingginya gunung, Tuhan dapat merobohkan ketinggiannya, menghanyutkan dengan kasih anugerah-Nya bahkan membebaskan dengan sempurnanya dari segala tuntutan dosa itu. Oleh anugerah raja itu, hamba yang berhutang banyak itu dibebaskan. Hal ini menggambarkan kepada orang percaya bahwa anugerah Tuhan itu dapat membebaskan manusia dengan sempurna dari segala dosanya, bagaimana berat dan besarnya dosa itu.

Kebenaran ini menuntut kepada orang percaya untuk menunjukkan perbuatan yang baik, perangai yang lemah lembut, cinta kasih kepada sesama manusia, takut dan hormat kepada Tuhan, setia menggenapi pesan-Nya yang telah diamanatkan-Nya yakni berbelas kasih dengan mengampuni orang yang bersalah sama seperti Kristus telah mengampuni. Sambil memikirkan ajaran Tuhan Yesus Kristus ini, Rasul Paulus mengingatkan semua orang di Efesus, hendaknya mereka saling mengasihi dan saling mengampuni satu dengan yang lain, sebagaimana Allah Bapa di dalam Kristus sudah mengampuni mereka (Ef.4:32). Herbert Lockyer mengatakan, "saling mengampuni memperlihatkan kerendahan hati yang sudah menerima pengampunan ilahi." ${ }^{36}$

Sehubungan dengan penjelasan di atas, Richard Strauss menegaskan bahwa dalam suatu tindakan yang menunjukan belas kasihan dan kasih karunia yang tidak ada bandingnya, raja itu

\footnotetext{
${ }^{35}$ R. A Jaffray, Perumpamaan Tuhan Yesus (Bandung: Kalam Hidup, t.t.), 40

${ }^{36}$ Herbert Lockyer, All the Apostles of the Bible (Grand Rapids: Zonervan, 1972), 115.
}

membebaskan seluruh hutangnya, mengampuninya sama sekali. Ia sendiri yang membayar lunas hutang hamba itu. Raja tersebut menggambarkan Allah, dan apa yang dilakukannya memperlihatkan harga mahal yang dibayar Allah untuk pengampunan kita yang kekal. ${ }^{37}$ Hal-hal inilah yang diinginkan oleh Yesus, supaya dapat teraplikasi dalam kehidupan orang percaya. Apabila seseorang telah mengalami pengampunan dari Allah, maka dengan sendirinya ia telah menjadi warga kerajaan sorga. Itulah sebabnya setiap orang yang telah menjadi anggota kerajaan sorga punya hakekat untuk mengampuni sesamanya. Dalam arti bahwa setiap orang percaya yang sudah menjadi warga kerajaan sorga sudah mempunyai sikap atau sifat untuk mengampuni sesamanya.

\section{Konsekuensi bagi Orang yang Tidak Mengampuni}

Dalam Matius 18:28-30 dijelaskan tentang hamba yang jahat itu tidak menaruh belas kasihan kepada temannya yang berhutang kepadanya. Hal ini jelas diberitahukan bahwa hamba itu tidak memahami apa telah yang dilakukan raja kepadanya. Hamba ini masih berpikir bahwa ia harus melunasi hutangnya dan bahwa dengan sesuatu cara ia dapat melunasinya. Itulah yang terjadi kemudian, sebagaimana yang dikatakan dalam ayat 28-30. Ayat-ayat ini menjelaskan betapa fatalnya tindakan hamba itu, di mana menyatakan ketidaksetiaannya dalam hal mengampuni. Ini adalah konsekuensinya karena tidak benar-benar memahami kenyataan dan kebesaran dari pengampunan Allah terhadap diri sendiri.

Itulah sebabnya ketika ia pergi keluar dan bertemu dengan hamba yang lain yang berhutang kepadanya sebanyak seratus dinar dan ia menangkapnya dengan mencekiknya dan menuntut pembayaran hutangnya. Hamba itu memohon kepadanya untuk bersabar, sambil berjanji akan membayar seluruh hutangnya. Tetapi orang itu tidak mau, ia menjebloskan kawannya itu ke dalam penjara sampai seluruh

${ }^{37}$ Richard Strauss, Hubungan Yang Harmonis (Bandung: Kalam Hidup, 1985), 111. 
hutangnya lunas. Richard Strauss berkata, "Alangkah munafiknya telah diampuni begitu besar tetapi menolak untuk mengampuni yang kecil." ${ }^{38}$

Hal yang serupa terlihat kepada orang-orang percaya di Korintus. Mereka tidak memahami arti dari kasih karunia Allah dan kenyataan betapa besarnya pengampunan Allah bagi mereka. Richard Strauss dalam hal ini menjelaskan bahwa itulah masalah yang terjadi di Korintus. Orang-orang percaya saling menuntut di pengadilan karena masalah-masalah kecil. Mereka belum memahami arti dari kasih karunia Allah dan kenyataan betapa besar Allah telah mengampuni mereka. Lebih baik kita sendiri yang menderita hinaan, sakit hati, kerugian atau kerusakan dari pada mangambil resiko yang sekecil-kecilnya untuk melukai hati orang-orang percaya lainnya. ${ }^{39}$ Itulah inti pengampunan, membayar sendiri kerusakankerusakannya, membatalkan sikap tuntutan, membuang hak untuk membalas dendam dalam bentuk apapun, kasar atau halus, terang-terangan maupun diam-diam. Itulah yang dilakukan Allah bagi orang lain.

Dalam kisah tentang apa yang terjadi pada hamba yang tidak mau mengampuni dalam perumpamaan Yesus adalah sesuatu yang tidak terpuji dan membawa kerugian yang besar. Dalam ayat 31-34 dijelaskan bahwa ketika hamba-hamba yang lain melihat apa yang telah dilakukannya, betapa sedihnya kawan-kawan yang melihat perbuatan yang keji itu dan akhirnya melaporkan hal itu kepada raja. Ia memanggil hamba itu dan menegurnya serta menyerahkannya kepada algojo-algojo sampai ia melunaskan seluruh hutangnya.

Yesus menutup cerita ini dan berkata, "maka Bapa-Ku yang di sorga akan berbuat demikian juga terhadap kamu, apabila kamu masingmasing tidak mengampuni saudaramu dengan segenap hatimu" (Matius 18:21-35). Richard Strauss berkata:

Itu adalah pikiran yang menakutkan. Kita tidak tahu pasti siapa algojo-algojo itu, tetapi beberapa orang berpendapat bahwa mereka adalah algojo-

\footnotetext{
${ }^{38}$ Ibid, 111.

${ }^{39}$ Ibid, 113.
}

algojo di dalam hati yang menyakiti mereka yang tidak mau menampuni asamnya kemarahan, kebencian, kepahitan hati, kejahatan, perasaan bersalah, depresi, dan keputusasaan yang menggerogoti dan menghancurkan kita. Sungguh suatu keadaan yang mengerikan. ${ }^{40}$

Pengampunan menuntut harga yang tinggi bagi diri sendiri tetapi harganya akan lebih tinggi jika diri sendiri menahannya terutama menyangkut algojo-algojo di dalam hati. Selanjutnya, Jonathan A. Trisna menegaskan bahwa hal ini dilakukan karena perintah dan kehendak Allah dan untuk kedamaian dan kesejahteraan diri sendiri (agar tidak terus disiksa algojo-algojo). ${ }^{41}$

Jadi, jelas bahwa konsekuensi bagi orang yang tidak mau mengampuni adalah menerima kerugian yang besar. Terjadi siksaan batin, dan tidak akan menikmati damai sejahtera karena tidak mengikuti perintah Tuhan dan kehendak Allah untuk dilakukan dalam hidup.

\section{Aplikasi Praktis Konsep Pengampunan}

Aplikasi yang dapat ditarik bertdasarkan pengertian di atas adalah pertama, mengampuni secara sukarela buka dengan paksaan. Kedua, mengampuni secara terus menerus. Ketiga, mengampuni tanpa batas. Fakta Kristus tentang pengampunan sudah terbukti melalui penyingkapan maksud Allah dengan merealisasikan firman-Nya. Pemahaman akan konsep pengampunan pastilah membawa implikasi yang sangat relevan. Pertama, dalam kehidupan orang percaya, tetapi juga dalam pelayanan gereja masa kini. Berikut ini akan diuraikan aplikasi konsep pengampunan menurut Matius 18:21-35.

\section{Dalam Hidup Orang Percaya}

Aplikasi penting konsep pengampunan dihubungkan dengan hidup orang percaya yakni dalam membentuk suatu umat dimanifestasikan dalam sejarah. Dimana merealisasikan sifat pengampunan Kristus, baik secara pribadi

\footnotetext{
${ }^{40}$ Ibid, 113.

${ }^{41}$ Jonathan A. Trisna, Mengatasi Masalah Hidup
} (Bandung: Kalam Hidup, 1998. 
maupun dalam gereja Tuhan. Sifat pengampunan Kristus seharusnya dipraktekkan dalam hidup secara terus menerus. Karena inti dari ajaran Yesus tentang pengampunan menuntut pengaplikasikan seperti Kristus yang dengan kasih-Nya telah mengorbankan hidup-Nya.

Pengampunan Allah (Mat. 18:21-25) merupakan pola panutan bagi kehidupan orang Kristen. Artinya pengalaman-pengalaman yang dijalani melalui pengampunan-Nya memungkinkan orang percaya mengikuti sikap-sikap hidup-Nya. Sehubungan dengan hal di atas, $\mathrm{H}$. E. Fosdick memberi beberapa kesimpulan tentang makna pengampunan Yesus bagi orang percaya:

1. Yesus telah memberikan kepada dunia sebagian gagasan penting tentang Allah. 2. Untuk pemikiran lain, Yesus telah mengangkat nilai manusia dari harga diri-Nya sendiri. 3. Dari sejarah yang dikerjakan Yesus, Dia telah membuat manusia percaya, memungkinkan memperoleh kembali moral pembaharuan. 4. Dia telah memberi kepada dunia teladan etika yang agung. 5. Sejarah Yesus telah memberikan kepada dunia suatu pertunjukan yang sangat menarik dan mengesankan, dari pengorbanan yang dilakukan bagi orang lain....Hal ini memimpin kita pada pokok persoalan : Yesus telah menyalurkan suatu maksud loyalitas untuk ketaatan yang agung pada generasi sejak kedatangan-Nya. ${ }^{42}$

Jadi aplikasi yang dapat ditarik dalam bagian ini adalah bahwa setiap orang percaya harus mempraktekkan sifat pengampuan yang dibuat Kristus bagi orang lain, karena sifat ini dipraktekkan oleh Yesus sendiri. Mengampuni orang yang bersalah dengan pengampunan yang tulus iklas sama seperti Yesus mengampuni dosa manusia.

Pernyataan di atas sungguh jelas bahwa tidak akan terjadi pengampunan tanpa kerelaan Yesus untuk berkorban membatasi diri dalam realitas kehidupan manusia. Keseluruhan hidup-Nya adalah contoh atau model atau gaya hidup Kristen. Sehubungan dengan hal ini, Darmawi Jaya mengatakan:

${ }^{42}$ H. E. Fosdick, “Jesus, The Messiah, “Man's Need And God's Gift (Grand Rapids: Baker Book House, 1976), 265.
Yesus sendiri nampak menolak jalan kekerasan. Dengan dinamika dan sabda penampilan-Nya, Ia bisa menimbulkan huru hara, Ia bisa menundukkan lawan dengan kekerasan. Tidak ada yang begitu diperlengkapi dengan kekuatan dan ketahanan seperti Yesus. Tetapi Dia tahu bahwa karya kasih Allah tidak bisa dibela, dilindungi dengan kekuatan atau paksaan. Ia tahu bahwa salah satu kekuatan dunia adalah tindakan pengorbanan melalui pengampunan. ${ }^{43}$

Rasul Paulus memahami pengampunan Yesus didasarkan dengan kasih (Rm. 3:24-26). Oleh sebab itu pengampunan harus didasarkan dengan kasih (1 Kor. 13:3). Pengampuan dengan kasih berarti orang percaya meletakkan kekuasaan dan kemampuan intelektual jika itu keuntungan orang lain. Dalam konteks pembahasan yang berada dalam perbedaan pendapat diantara murid-murid, Yesus menggunakan suatu perumpamaan untuk menjelaskan tetang teladan Yesus Kristus. Sebab hal tersebut, menurut Warren W. Wiersbe "tidak akan diselesaikan dengan peraturan atau ancaman." ${ }^{44}$ Tetapi pola yang diberikan Yesus Kristus adalah pola hidup-Nya sendiri yakni mengampuni secara sempurna, tanpa batas dan terus menerus. Jika Matius mengambil contoh tertinggi ajaran Yesus itu berarti implikasi konsep pengampunan telah menjadi bagian hidupnya. Berarti orang percaya juga dapat mengikuti teladan Yesus. Menurut Darmawijaya, "Kredibilitas terletak disini untuk membangun suatu hubungan yang sejahtera dengan Allah perlu perjuangan hidup dan mati." ${ }^{45}$

Jadi, implikasi baik bagi orang percaya adalah membangun suatu kehidupan yang utuh dengan memiliki sikap mengampuni kepada orang lain yang bersalah. Mengampuni orang secara sempurna, tanpa batas, dan terus menerus.

\section{Dalam Pelayanan Gereja Masa Kini}

Aplikasi penting dalam konsep pengampunan yang relevan dalam pelayanan gereja masa

\footnotetext{
${ }^{43}$ Darmawijaya, Gelar-Gelar Yesus (Yogyakarta: Kanisius, 1987), 118.

${ }^{44}$ Warren W. Wiersbe, Sukacita Dalam Tuhan

(Bandung: Kalam Hidup, 1978), 53.

${ }^{45}$ Darmawijaya, Gelar-Gelar Yesus, 118.
} 
kini terlihat jelas dalam ajaran Yesus melalui perumpamaan. Dimana pola yang diajarkan Yesus merupakan model yang sangat efektif bagi gereja masa kini. Karena penyingkapan konsep pengampunan oleh Yesus sangat jelas memperlihatkan maksud Allah bagi gereja yang sangat penting untuk dipahami. Pengampunan adalah sebagian dari gaya hidup Tuhan Yesus. Ia mengampuni orang lumpuh (Mat. 9:2), perempuan yang berdosa (Luk. 7:47), perempuan yang tertangkap basah berbuat zinah (Yoh. 8:10-11), bahkan mengampuni orang yang memakukan dia ke salib (Luk. 23:34). Sebenarnya seluruh tujuan Yesus datang ke dunia ini adalah untuk mati supaya dosa kita dapat diampuni. Dengan menerima pengampunan ilahi yang luar biasa ini kita disanggupkan untuk dapat mengampuni orang lain. ${ }^{46}$

Selanjutnya, Leon Morris mengutip pernyataan John R. W. Stott yang menjelaskan bahwa:

Pengampunan adalah suatu konsep perubahan yang dinamis. Pengampunan menolak terperangkap ke dalam suatu deterisme fatalistik (aliran atau pandangan yang percaya bahwa nasib manusia ditentukan oleh takdir. Pengampunan sadar akan kenyataan kejahatan, kesalahan dan ketidakadilan, namun berusaha menanggapi kesalahan dengan cara yang kreatif untuk kemungkinan-kemungkinan baru. Pengampunan memberikan isyarat pendekatan terhadap kesalahan dengan syaratsyarat, bukan mengenai pendamaian berapapun biayanya, bukan tujuan yang merusak untuk membinasakan orang-orang yang melakukan kejahatan namun suatu keinginan untuk mengusahakan pembentukan kembali masa depan mengingat kesalahan, dengan cara yang mungkin paling kreatif. ${ }^{47}$

Hal lain juga, Henry C. Thiessen menegaskan bahwa karena Kristus telah menanggung segala hukuman dosa manusia maka kini Allah telah menghapus hukuman itu dalam hal orang percaya kepada Kristus (Kis. 13:38, 39; Rom. 8, 1, 33, 34; 2 Kor. 5: 21. Inilah yang dinamakan pengampunan dosa (Rom. 4:7; 4: 32: Kol. 2:13). Kemataian Kristus telah memungkinkan

\footnotetext{
${ }^{46}$ Goldie Bristol dan Carol McGinnis, 33.

${ }^{47}$ Leon Morris, Salib Yesus_(Malang: Seminari Alkitab Asia Tenggara, 1994), 310.
}

pengampunan dosa tetapi tidak mewajibkan, karena Kristus mati secara sukarela dan bukan karena terpaksa. Allah tetap menentukan atas syarat-syarat apakah manusia boleh menerima pengampunan dosa. Hal ini telah dilakukan-Nya dengan menyatakan bahwa Ia mengampuni orang yang bertobat dan percaya kepada anakNya. ${ }^{48}$ Haruslah disadari bahwa karya Yesus Kristus merupakan pengorbanan terbesar Dari Allah. Sehubungan dengan hal ini John F. Walvoord menjelaskan bahwa:

1. Allah dibenarkan dalam mengampuni dosa. Atas dasar kemetian Kristus Allah sepenuhnya dibenarkan dalam pengampunan dosa di dalam mana Kristus telah membayar harganya secara penuh. 2. Allah dibenarkan dalam mengaruniakan kebenaran sebagai pelengkap terhadap pengampunan dosa.Jalan pendamaian membuka pintu bagi Allah untuk memberikan kebenaran Kristus kepada orang berdosa seperti yang dibayangkan lebih dahulu dalam persembahan-persembahan berbau harum di Perjanjian Lama. Karena ini Allah dapat membenarkan orang berdosa dam menerimanya atas jasa dari anak-Nya. 3. Allah dibenarkan dalam mengaruniakan anugerah kepada orang berdosa. Setelah sepenuhnya dipuaskan oleh kematian Kristus. Sekarang Allah bebas untuk mencurahkan segala berkat yang ditunjukkan oleh hati-Nya yang kasih ke atas manusia, objek dari anugerah-Nya. ${ }^{49}$

Fakta bahwa pengampunan merupakan karya Yesus Kristus yang menjamin keselamatan manusia. Goldie Bristol mengutip pernyataan David Augsburger menjelaskan bahwa "pengampunan memulihkan yang sekarang, menyembuhkan yang akan datang dan membebaskan kita dari masa lalu." ${ }^{50}$

Selanjutnya F.F Bruce menegaskan bahwa "Injil adalah berita pengampunan, tidak bisa menjadi sebaliknya, sebab itu adalah Injil Allah dan Allah adalah Allah yang mengampuni." Berita pengampunan Yesus seharusnya menjadi sifat hakiki dalam hidup gereja masa kini. Karena sifat ini merupakan kasih terbesar dari

${ }^{48}$ Henry C. Thiessen, Teologi Sistematika (Malang:

Gandum Mas, 1995), 422.

${ }^{49}$ John F. Walvoord, Yesus Kristus Tuhan Kita

(Surabaya: Yakin, 1969), 163.

${ }^{50}$ Goldie Bristol, 166.

${ }^{51}$ F. F. Bruce, Ucapan Yesus Yang Sulit, (Malang:

Seminar Alkitab Asia Tenggara, 1999, 75. 
Yesus sehingga Dia mengorbankan hidup-Nya bagi keselamatan umat manusia. Akibat bagi orang yang memahami maksud Allah ialah hidup penuh damai, sukacita dan sejahtera didalamnya. Maksud Yesus adalah membentuk suatu keutuhan sebagai tubuk Kristus.

Jadi implikasi yang dapat ditarik dalam bagian ini adalah apabila anggota jemaat melakukan dosa, sikap yang perlu diambil adalah tidak membenci tetapi menunjukkan belas kasihan dengan mengampuni seperti yang diajarkan Yesus. Dengan demikian sifat pengampunan Kristus dapat diwujudkan dalam tindakan pelayanan gereja masa kini. Hal ini harus menjadi dasar motivasi dalam pelayanan gereja masa kini untuk membentuk keutuhan sebagai pengikut Kristus secara rohani dan direalisasikan dalam kehidupan berjemaat sebagai murid Kristus.

\section{KESIMPULAN}

Tuhan Yesus memerintahkan orang percaya untuk saling mengampuni. Pengampunan yang diberikan Allah di dalam Yesus Kristus didasarkan pada belas kasihan Allah. Oleh belas kasihan raja itu, hamba yang berhutang banyak itu dibebaskan. Hal ini menggambarkan kepada orang percaya bahwa belas kasihan Tuhan itu dapat membebaskan manusia dengan sempurna dari segala dosanya, bagaimana berat dan besarnya dosa itu.

Allah menuntut kepada orang percaya untuk menunjukkan perangai yang lemah lembut, cinta kasih kepada sesama manusia, takut dan hormat kepada Tuhan, serta menanggapi pesan yang diamanatkan-Nya yakni berbelas kasih dengan mengampuni orang yang bersalah sama seperti Kristus telah mengampuni. Sifat pengampunan Kristus harus nampak bagi orang percaya.

Pengampunan merupakan karya terbesar dari Allah yang didasarkan pada pengorbanan Yesus di kayu salib. Karena arti dari ucapan Yesus tentang mengampuni tujuh puluh kali tujuh kali adalah mengampuni tanpa batas. Karena inti dari ajaran Yesus tentang pengampunan menuntut pengaplikasian seperti Kristus yang dengan kasih-Nya telah mengorbankan hidupnya. Pengampunan Allah (Mat. 18:21-35) merupakan pola panutan bagi kehidupan orang percaya. Artinya pengalaman-pengalaman yang dijalani Yesus melalui pengampunan-Nya memungkinkan orang percaya mengikuti sikapsikap hidup-Nya. Keseluruhan hidup-Nya adalah contoh atau model atau gaya hidup Kristen. Itulah sebanya orang percaya dan gereja masa kini harus menunjukkan sifat pengampunan Kristus sebagai pengikut Kristus.

\section{KEPUSTAKAAN}

Bauer, Walter. Greek English Lexicon of the Old Testamen and Other Early Christian Literature. Chicago: University of Pres, 1979.

Bavink, J. H. Sejarah Kerajaan Allah. Jakarta: BPK Gunung Mulia, 1982.

Berghe, P. Marc Van Den. Akulah Jalan. Jakarta: BPK Gunung Mulia, 1994.

Boice, James Montgomery. PerumpamaanPerumpamaan Tuhan Yesus. Surabaya: Yakin, 1983.

Bristol, Goldi dan Caril McGinnis. Haruskah Saya Mengampuni. Bandung: Kalam Hidup, 1982.

Bromiley, Geoffey W. The International Standar Bible Encyclopedia. Grand Rapids: William B. Eedmans Publishing Company, 1979.

Bruce, F. F. Ucapan Yesus Yang Sulit. Malang: Seminar Alkitab Asia Tenggara, 1999.

Darmawijaya. Gelar-Gelar Yesus. Yogyakarta: Kanisius, 1987.

Ensiklopedi Alkitab Masa Kini Jilid I. Jakarta: Yayasan Komunikasi Bina Kasih/OMF, 1997.

Ensiklopedia Alkitab Masa Kini Jilid 2 M-Z. Jakarta: Yayasan Komunikasi Bina Kasih/OMF, 1996.

Ferguson, Ben. Cara Mengatasi 12 Maslah Kehidupan. Solo: Dabara Publisher, 1995.

Fosdick, H.E. Jesus, The Messiah, Man's Need And God's Gift. Grand Rapids: Baker Book House, 1976.

Gaebelein, Frank E. The Expositor's Bible Comentary Volume 8. Grand Rapids, Michigan: Regency Reference Library Zondervan Publishing House, 1984. 
Graham, Billy. Hingga Harmagedon. Bandung: Lembaga Literatur Baptis, 1981.

Guthrie, Donald. Teologi Perjanjian Baru. Bandung: BPK Gunung Mulia, 1993.

Heer, J.J.De. Tafsiran Alkitab Injil Matius 2. Jakarta: BPK Gunung Mulia, 1985.

Jaffray, R.A. Perumpamaan Tuhan Yesus 2. Bandung: Kalam Hidup, 1999.

NewmanJr, Barclay M. Kamus Yunani Indonesia untuk Perjanjian Baru. Jakarta: BPK Gunung Mulia, 1994.

Lockyer, Herbert. All the Apostles of the Bible. Grand Rapids: Zonervan, 1972.

Morgan, G. Campbell. The Gospel According to Mattew. Old Tappan, New Jersey: Fleming H. Revell Company, 1978.

Morris, Leon. Salib Yesus. Malang: Seminari Alkitab Asia Tenggara, 1994.

Moulton, Harol K. The Analytical Greek Lexicon Revised. Grand Rapids: Zondervan, 1978.

Rienecker, Frits. A Linguistic key to the Greek New Testament. Grand Rapids: Zondervan Publishing House, 1976.

Ryrie, Charle C. Teologi Dasar 1. Yogyakarta: Yayasan ANDI, 1991.

Sitompul, A.A. Sinopsis Ketiga Injil. Jakarta: Lembaga Alkitab Indonesia, 1993.

Strauss, Richard. Hubungan yang Harmonis. Bandung: Kalam Hidup, 1985.

Swindol, Charles R. Tingkatkan Pelayanan Anda. Jakarta: BPK Gunung Mulia, 1985.

Tafsiran Alkitab Masa Kini 3. Jakarta: Yayasan Komunikasi Bina Kasih/OMF, 1976.

Trisna, Jonathan A. Mengatasi Masalah Hidup. Bandung: Kalam Hidup, 1998.

Thiessen, Henry C. Teologi Sistematika. Malang: Gandum Mas, 1995.

Vorlander, H. The New International Dictionary of The New Testament Teology Volume 3. Grand Rapids: William B. Eerdmans Publishing Company, 1979.

Walvoord, John F. Yesus Kristus Tuhan Kita. Surabaya: Yakin, 1969.

Walvoord, Jhon F. dan Roy B. Zuck. The Bible Knowledge Commentary. Engliand: Victory Book Publication, 1984.

Wiersbe, Warren W. Meet Yourself in the Parables. Victor Book: Publication Inc., 1979.
Wiersbe, Warren W. Sukacita Dalam Tuhan. Bandung: Kalam Hidup, 1978. 